\title{
Egzisztenciális predikáció és térbeli lokalizáció a magyarban
}

\author{
Gécseg Zsuzsanna \\ SZTE Francia Tanszék
}

\begin{abstract}
Összefoglaló
A tanulmány arra a kérdésre keresi a választ, hogy milyen szintaktikai, szemantikai és pragmatikai tényezők befolyásolják a térbeli lokalizációt jelölő összetevő jelenlétét és az alanyhoz viszonyított helyzetét a magyar egzisztenciális szerkezetekben. A vizsgálat egy 205 egzisztenciális megnyilatkozást tartalmazó 'pilot' korpusz elemzésén alapul. A vizsgált tényezők: az alany szintaktikai pozíciója és referenciális tulajdonságai (puszta köznév vs. névelős köznév), valamint a megnyilatkozás kontextuális jellemzői.
\end{abstract}

Kulcsszavak: létezést állító egzisztenciális megnyilatkozás, lokalizáló egzisztenciális megnyilatkozás, térbeli lokalizáció, leíró funkció, diskurzustopik, rendelkezésre állás

\section{Bevezetés}

Az egzisztenciális szerkezetek szemantikai funkciója egy referens létezésének vagy valahol való jelenlétének állítása. Ebből a funkcióból vezethetők le az ilyen szerkezetek formai jellemzői is: rendszerint egy létezést jelentő igét tartalmaznak (ami a magyarban a van), az alanyuk pedig nem specifikus ${ }^{1}$ referenciájú határozatlan kifejezés. $^{2}$

Sok esetben egy (vagy több) lokatívuszi összetevő is megjelenik a mondatban általában a tagmondat elején vagy végén -, amely legtöbbször térbeli (1) vagy időbeli (2) lokalizációt fejez ki. A lokatívuszi kifejezés jelenléte nem mindig kötelező (3).

a. Van egy csiga a levelek között.

b. A levelek között van egy csiga.

a. Tegnap lakógyülés volt.

b. Lakógyűlés volt tegnap.

(3) Vannak boszorkányok.

${ }^{1}$ A nem specifikus terminus az Enç (1991) szerinti értelemben használatos itt. Eszerint a specifikus határozatlan kifejezések partitivuszi értelmezésűek, azaz egy olyan halmaz valamely elemét jelölik, amely már jelen van a társalgási univerzumban. A nem specifikus határozatlan kifejezések ezzel szemben nem partitivuszi értelmezésűek. Az ilyen értelemben vett nem specifikus kifejezéseket gyenge vagy egzisztenciális értelmezésű kifejezésnek is szokás nevezni (l. többek között Milsark 1974; de Hoop 1995; Maleczki 1999).

${ }^{2}$ A tanulmány csak érintőlegesen foglalkozik az ún. esemény-egzisztenciális (Kálmán 2001) vagy egzisztenciális olvasatú (Kiefer 2006), ill. egzisztenciális aspektusú mondatokkal (Maleczki 2001; Németh 2012), amelyek valamely esemény létezését állítják, és az „előfordult már, hogy" kezdetű fordulattal parafrazálhatók (pl. Járt már Andi Jordániában) 
Az egzisztenciális szerkezeteknek tekintélyes szakirodalma van, ugyanakkor mind a magyarra, mind a más nyelvekre vonatkozó munkákban megfigyelhető, hogy az általánosítások nagy része nem ténylegesen elhangzott megnyilatkozásokon, hanem kontextus nélküli, kreált mondatokon alapul. Így arra nézve sem történhettek még átfogó vizsgálatok, hogy hogyan befolyásolja a kontextus az egzisztenciális szerkezetek szintaktikai megformálását, különös tekintettel a lokatívuszi összetevő megjelenésére az ilyen szerkezetekben.

Ebben a tanulmányban arra a kérdésre keresem a választ, hogy melyek azok a szintaktikai, szemantikai és pragmatikai tényezők, amelyek hatással lehetnek a térbeli lokalizációt kifejező kifejezés kötelező vagy fakultatív voltára, valamint szintaktikai pozíciójára a magyar nyelvű semleges ${ }^{3}$ egzisztenciális mondatokban. Kiinduló hipotézisem Comorovski (1995), Van de Velde (2005), valamint Partee-Borschev (2007) alapján az, hogy valamiféle (tágabb értelemben vett) lokalizáció mindenfajta egzisztenciális állításnak lényegi része, akkor is, ha ez a lokalizáció nem jelenik meg egy hangalakkal bíró összetevő formájában. Kérdés azonban, hogy mi teszi lehetővé, hogy bizonyos körülmények között implicit maradjon ez a lokalizáció.

A vizsgálat egy 205 magyar egzisztenciális megnyilatkozásból áló annotált korpuszon alapul, amelyet a Google keresőprogram segítségével álítottam össze. A lehetséges tényezők közül az alany szintaktikai pozícióját és referencialitását (puszta köznév vs. névelős köznév), valamint a kontextus egyes jellemzőit vizsgálom.

A tanulmány a következőképpen épül fel: a 2. részben áttekintést adok azokról a megközelítésekről, amelyek két nagy szemantikai kategóriát különítenek el az egzisztenciális konstrukciókon belül, a létezést állító és a lokalizáló egzisztenciális szerkezetek kategóriáját. A 3. részben röviden bemutatom az elemzések alapjául szolgáló korpuszmintát. A 4. részben a magyar egzisztenciálisok alanyának szintaktikai pozíciója és a lokatívusz kötelezősége közti összefüggésre térek ki. Az 5. részben amellett érvelek, hogy a hangalakkal bíró lokatívuszi összetevőt kötelezően tartalmazó szerkezetek tipikusan leíró funkciójú megnyilatkozásokban jelennek meg, míg az opcionális lokatívusszal járó megnyilatkozások uralkodó funkciója névelős alany esetén egy új topik bevezetése a diskurzusba, puszta köznévi alany esetén pedig a megnyilatkozás azt implikálja, hogy az újonnan bevezetett alany a diskurzus valamely résztvevőjének a rendelkezésére áll. A 6. részben a lokatívuszi összetevő szintaktikai pozícióját befolyásoló tényezőkről esik szó, végül a tanulmány rövid konklúzióval zárul.

\section{Az egzisztenciális szerkezetek két alosztálya}

Az egzisztenciális szerkezetek pontos behatárolásában nincs teljes egyetértés a nyelvészek között. A különféle megközelítések alapján két nagy csoport különíthető el az egzisztenciálisnak tekintett mondatok körén belül. Az első csoportot az ún. „valódi egzisztenciálisok” (real existentials), „létezést állítók” (predication of existence), vagy röviden „egzisztenciális mondatok" (existential sentences)

\footnotetext{
${ }^{3}$ Semleges mondat alatt az olyan mondatokat értem, amelyekben nincs topikalizált, fókuszált vagy tagadott kifejezés, és minden fő összetevő azonos hangsúllyal ejtett (Kálmán 1985a; 1985b; Puskas 2000). Egy semleges egzisztenciális mondatban az ige hangsúlytalan, ha az alany az ige előtt, az igemódosító pozíciójában van.
} 
alkotják, míg a második csoportba a „lokatívuszi egzisztenciális” (locative existential) vagy „lokatívuszi” (locative), „lokalizációt állító” (predication of location) szerkezetek tartoznak (I. többek között Lyons 1967; Van de Velde 2005; Partee-Borschev 2007; Koch 2012; Hegedűs 2013; Creissels 2014; McNally 2016). Ebben a tanulmányban a létezést állitó egzisztenciális és a lokalizáló egzisztenciális terminusokat fogom használni a kétféle típusú egzisztenciális állítás jelölésére.

A létezést állító egzisztenciálisok (3) legfőbb ismérve Koch (2012) szerint az, hogy nem tartalmaznak hangalakkal bíró lokatívuszi összetevőt, vagy ha igen, akkor opcionális a jelenléte. Ezzel szemben a lokalizáló egzisztenciálisok (1), ahogy a nevük is mutatja, mindig tartalmaznak egy hangalakkal bíró lokatívuszi összetevőt, és a mondat szemantikai funkciója az, hogy lokalizál egy (nem ismertnek tekintett) individuumot egy adott helyhez képest. ${ }^{4}$ Ez magyarázza a (4)-es mondat rosszul formáltságát explicit lokatívuszi összetevő nélkül.

a. Van egy csiga *(a levelek között).

b. Egy csiga van *(a levelek között).

A létezést állító mondatokat a szakirodalom sokszor többes számú határozatlan alanyú mondattal illusztrálja (3). Nem egyértelmű azonban az ilyen mondatok megítélése a magyarban. Viszket (2004) és Laczkó (2012) szerint ezekben a szerkezetekben az ige fókuszban áll, a mondat pedig verum fókuszt ${ }^{5}$ fejez ki. Ezt erősíti Viszket (2004) azon megfigyelése is, hogy a (3)-hoz hasonló mondatok azt implikálják, hogy az alany által denotált individuum(ok) létezése ellentmond az előzetes vélekedéseknek. Feltételezése szerint ezért van az, hogy nem lehet mindenfajta többes számú határozatlan alannyal „valódi egzisztenciális” mondatot alkotni:

*Vannak csigák.

Megfigyelhető, hogy a (3)-hoz hasonló mondatok nem egy konkrét individuum vagy individuum-csoport létezését állítják, hanem általánosságban állítják valamely individuum-osztály (vagy annak egy bizonyos részhalmaza) létezését. Koch (2012: 539) ezért az explicit lokatívuszi összetevő nélküli egzisztenciális mondatokat (6) a „generikus létezés” (generic existence) körébe sorolja. Ha egy ilyen mondatban (opcionális) lokatívuszi összetevő is szerepel (7), annak Koch (2012) szerint csupán az a funkciója, hogy specifikálja azt a helyet, amelyre érvényes a létezésről szóló állítás. ${ }^{6}$ Ilyenkor az egzisztenciális állítással érintett referenst egy nem specifikus határozatlan NP jelöli.

\footnotetext{
${ }^{4} \mathrm{~A}$ kétféle állitás közti különbséget többféle fogalomkészlettel próbálják megragadni. ParteeBorschev (2007) a perspektíva fogalmára építi megközelítését. Eszerint mind a (valódi) egzisztenciális mondatok, mind a lokalizáló mondatok egy Hely (Location) és egy Dolog (Thing) közti relációt jelölik, ahol a (valódi) egzisztenciális mondatban a Hely a perspektívaközpont, a lokalizáló mondatokban pedig a Dolog. Azt állítják továbbá, hogy a perspektívaközpont létezése mindig előfeltételezett (Partee-Borschev 2007: 156). Koch (2012) is amellett érvel, hogy csak a létezést állító egzisztenciálisok állítják explicit módon egy adott dolog létezését. A lokalizáló egzisztenciálisokban ezzel szemben ez a létezés adott (taken for granted) a beszélő számára, maga az állítás a lokalizálásra összpontosul.

${ }^{5} \mathrm{~A}$ verum fókusz terminust Höhle (1992) vezette be, és egy kijelentés igaz voltának hangsúlyozását jelöli.

6 "The locus [...] only specifies the local area of validity of the statement of existence" (Koch 2012: 538)
} 
(6) (Koch 2014: 539)

There are many unhappy people.

ott vannak sok boldogtalan nép

'Sok boldogtalan ember van.'

(7) (idem.)

There are many unhappy people in Africa.

ott vannak sok boldogtalan nép -ban Afrika

'Sok boldogtalan ember van Afrikában.'

Széles körben elfogadott nézet (I. például Comorovski 1995; Van de Velde 2005; Partee-Borschev 2007), hogy az egzisztenciális állítások lényeges mozzanata a létezőnek állított referens lokalizálása, ami a lokalizáló egzisztenciálisok esetén mindig hangalakkal bíró lokatívuszi összetevő révén történik. ${ }^{7}$ A (6)-hoz hasonló, létezést állító egzisztenciális mondatokról azt gondolhatjuk, hogy a hely, amihez képest az állítás értelmezhető, maga az egész fizikai világ, vagyis a maximális diskurzusuniverzum. Van de Velde (2005) bírálja ezt a megközelítést. Amellett érvel, hogy a generikus értelmezésű egzisztenciális mondatok voltaképpen egy nagyobb halmaz valamilyen részhalmazáról állítanak valamit. A (8) és (9) mondatok ennek megfelelően ekvivalensek egymással:

(8) Vannak boldogtalan emberek.

(9) Az emberek között vannak boldogtalanok.

Van de Velde nézete szerint szerint tehát az egzisztenciális állításokra univerzálisan jellemző lokalizációt az ilyen mondatokban nem térbeli, hanem partitív lokalizációként foghatjuk fel, ahol egy individuumcsoportot egy őt magában foglaló, nagyobb individuumcsoport részeként lokalizálunk. ${ }^{8}$

Mint ismeretes, az egzisztenciális mondatok predikátuma atelikus és határozottsági korlátozást mutat. Maleczki (1998; 1999; 2003) általánosítása értelmében „atelikus predikátumok akkor engednek meg gyenge értelmezésű alanyokat a magyarban, ha térben kötöttek" (Maleczki 1998: 276), aminek következtében mindig megjelenik az ilyen szerkezetekben a lokatívuszi összetevő. Koch fenti két mondata is alátámasztja ezt az általánosítást: a lokatívusz nélküli (6)-os mondat alanya generikusként értelmezett, míg a lokatívuszt tartalmazó (7)-es változat határozatlan alanya gyenge olvasatú.

A magyarban puszta köznévi alany esetén az alany szintaktikai pozíciója befolyásolja a lokatívusz kötelezőségét az egzisztenciálisokban: ha a puszta köznév az igemódosító pozíciójában van, a lokatívusz mindig kötelező (Maleczki 1998; 1999; 2003; Viszket 2004; Hegedűs 2013), azaz az ilyen mondatok mind a lokalizáló

\footnotetext{
${ }^{7}$ Kivéve persze az olyan elliptikus szerkezeteket, mint amilyet az alábbi példában láthatunk:

(i) Mi van a kosárban? - Egy barack.

${ }^{8}$ Van de Velde (2005) ezt a kiinduló hipotézist aztán kiterjeszti az összes egzisztenciális mondatra, a lokalizáló egzisztenciálisokra is.
} 
egzisztenciálisok csoportjába tartoznak. Ez magyarázza a (10a) mondat agrammatikalitását: ${ }^{9}$

(10) a. *Barack van.

b. Barack van a kosárban.

Az előzőkben láttuk, hogy puszta köznév lokatívuszi kifejezés nélkül is állhat az ige után. A (3)-as példából kiindulva azt gondolhatnánk, hogy ilyenkor mindig verum fókusszal van dolgunk a magyarban, és az alanynak generikus értelmezése van. Ez azonban csak a többes számú alanyokra érvényes. Az alábbi, Maleczki (2008)-ból származó példában az egyes számú alany nem generikus olvasatú, és a mondat semleges állításnak tekinthető, hiszen az alany ugyanolyan hangsúlyt kap benne, mint a létige: ${ }^{10}$

(Maleczki 2008: 137)

Van fagyi (a fridzsiderben).

Felmerül a kérdés, hogy amennyiben az atelikus predikátumok gyenge alanyának térben kötöttnek kell lenniük, akkor mi teszi lehetővé, hogy az ilyen gyenge olvasatú, ige után álló alany explicit lokatívusz nélkül forduljon elő. Többek között erre a kérdésre keresi a választ ez a tanulmány.

\section{A korpusz}

A tanulmányban bemutatott elemzések egy 205 magyar megnyilatkozásból álló annotált korpusz vizsgálatán alapulnak, melyek mindegyike egy-egy semleges egzisztenciális szerkezetet tartalmaz. A megnyilatkozásokat a Google keresőprogram segítségével gyűjtöttem össze. Olyan [alanyi NP + V] és [V + alanyi NP] sorokat kerestem, ahol

- $\quad$ az alany egyes számú puszta köznév vagy [egy N] alakú névszói szerkezet,

- $\quad$ az ige pedig a van ige jelen vagy múlt idejű egyes számú alakja.

Az alany névszói része a következő, konkrét dolgot jelölő főnevek köréből kerül ki: ember, nő, gyerek, kutya, bogár, fa, virág, lámpa, asztal, üdítő, bor, város, erdő és tó. A főnevek kiválasztását viszonylag nagy gyakoriságuk motiválta, továbbá az,

\footnotetext{
${ }^{9}$ A tanulmány egyik bírálója felhívja a figyelmet, hogy bizonyos kontextusokban elfogadható a (10a) mondat, például arra az állításra válaszolhatunk vele, hogy Semmi gyümölcs nincs itthon. Fontos azonban megjegyezni, hogy ebben az esetben nem semleges mondatról van szó, mivel a barack alany a kontrasztív topikra jellemző intonációt kapja, és kontrasztív az értelmezése is.

${ }^{10}$ Felmerülhet, hogy a különbséget az okozza, hogy a (3)-as példa alanya többes számú, míg a (6)-os példáé egyes számban áll. Ez azonban nem helytálló, mivel egyes számú határozatlan alany is állhat generikus mondatban (i), és többes számú puszta köznévi alany is állhat az ige után gyenge olvasattal (ii):

(i) Van túlvilág.

(ii) 'Vannak 'rózsák (a 'kertben).
} 
hogy élőlényt és élettelen objektumot, valamint megszámlálható és megszámlálhatatlan dolgot jelölő főnév (azaz anyagnév) egyaránt van köztük. ${ }^{11}$

Felmerülhet a kérdés, hogy egy írott korpusz esetén hogyan lehet eldönteni, hogy a kereső által kiszelektált szerkezet semleges vagy fókuszált összetevőt tartalmaz. Az elemek felszíni sorrendje alapján ez nem mindig eldönthető, prozódiai információk viszont nem állnak közvetlenül rendelkezésre. A kérdést ilyen esetben mindig a kontextus dönti el, a kontextuális információk alapján ugyanis kizárható (vagy megerősíthető) az alany esetleges kontrasztív értelmezése, illetve az is, hogy a megnyilatkozást milyen prozódiával kellene ejteni.

Az itt vizsgált korpusz összes ige előtti alanya az igemódosító pozíciójában van: közvetlenül megelőzi az igét (ezt a mintavétel biztosítja), mondathangsúlyt kap, de nincs kontrasztív értelmezése, és az utána következő létige hangsúlytalan.

A (12)-es példa második mondatában szereplő egy kenyér alany közvetlenül megelőzi az igét, mégsem tekinthetjük fókuszáltnak, mivel a kontextus nem indokolná a kontrasztív értelmezést. A legtermészetesebb hangsúlyozása semleges mondatnak felel meg, azaz az ige hangsúlytalan, az után álló lokatívuszi összetevő pedig ugyanolyan hangsúlyt kap, mint az ige előtti alany.

Az ókécskei Herczeg Győzőné Tekes Mária a Felvidékről jött haza látogatóba testvéréhez. Egy kenyér volt a hóna alatt.

Mindezek alapján Hegedűs (2013) hipotézisével egyetértve az ilyen szerkezetek alanyáról azt feltételezem, hogy a semleges mondatokban szereplő ige előtti puszta köznévhez hasonlóan az igemódosító pozíciójában foglal helyet.

A 205 megnyilatkozás 73 százalékában van térbeli lokalizációt jelölő kifejezés, ám ezeknek nem mindegyike kötelező ${ }^{12}$ összetevő. Az esetek 60 százalékában a lokatívuszi összetevő megelőzi az alanyt, leginkább a topik, ritkábban az igemódosító pozíciójában van. A maradék 40 százalékban a lokatívusz közvetlenül a létige után áll.

\section{Az alany szintaktikai pozíciója}

Az adatokból egyértelműen kiderül, hogy az alany szintaktikai pozíciója hatással van a lokatívuszi kifejezés kötelezőségére. Függetlenül attól, hogy puszta köznévi vagy determinánssal bevezetett az alany, amennyiben az igemódosító pozíciójában

\footnotetext{
${ }^{11}$ A megszámlálható és megszámlálhatatlan főnevek közti szemantikai különbséget az atomosság, ill. homogeneitás fogalmával szokás megragadni. Ez annyit tesz, hogy a megszámlálható főnév által denotált halmaz egymástól jól elkülöníthető tulajdonságú minimális alkotóegységeket tartalmaz, míg a megszámlálhatatlan fönév által denotált halmaz „homogén”, bármely részhalmaza ugyanazokkal a tulajdonságokkal rendelkezik, mint az egész halmaz (Link 1983). A magyarban a megszámlálható főnevek többes számba tehetők, míg a megszámlálhatatlanok nem. Sok főnév bizonyos jelentésében anyagnévként (azaz megszámlálhatatlanként) viselkedik, míg más jelentésében megszámlálhatóként. Ilyen például a bor főnév, amely alapértelmezésben anyagnévként viselkedik, de 'borfajta' értelmezésében megszámlálható.

${ }^{12} \mathrm{~A}$ tanulmány mindkét bírálója felveti azt a kérdést, hogy miként állapítottam meg, hogy egy összetevő kötelező-e. Ezen a ponton a korpuszelemzésbe belépett az introspekció: saját magam ítéltem meg, hogy az adott kontextusban elfogadható-e a lokatívusz nélküli változat.
} 
áll, kötelező a lokatívusz jelenléte, vagyis lokalizáló egzisztenciális megnyilatkozásokkal van dolgunk:

(13) a. Bogár van a házi pirospaprikámban.

b. "Bogár van.

(14) a. Az épületben egy nő volt, aki meghalt a tǔzben.

b. *Egy nő volt, aki meghalt a tüzben.

Ezzel szemben a korpusz ige utáni alanyt tartalmazó megnyilatkozásainak közel fele nem tartalmaz semmilyen térbeli lokalizációt, de a többi megnyilatkozás kb. egyharmadában is elhagyható a lokatívuszi összetevő. Ezek tehát a létezést állító mondatok csoportjába sorolhatók.

(15) Például van kutya, amelyik nem engedi, hogy elvegye a gazda az ételét.

(16) Szomjas vagy? Van üdítő, víz, tej.

(17) Volt egy ember, aki mindenkinek megbocsátott.

(18) Volt egy erdő. Egy nagyon sürủ erdő.

(19) Volt egy nő, állt a sarokban.

A (20) és (21) alatti példák ugyanakkor azt mutatják, hogy bizonyos esetekben nem hagyható el a lokatívusz az ige utáni alanyú egzisztenciálisokban sem, vagyis az ilyen mondatok a lokatívuszi összetevő kritériuma alapján lokalizáló egzisztenciálisoknak tekintendők.

(20) a. Ez a ruha egy pántos egyberuha, ami rózsaszín és van egy virág rajta.

b. *Ez a ruha egy pántos egyberuha, ami rózsaszín és van egy virág.

a. Volt egy bogár a szemembe. Anya megint cselhez folyamodott.

b. "Volt egy bogár. Anya megint cselhez folyamodott.

Felmerül a kérdés, hogy mi teszi lehetóvé a (15)-(19)-hez hasonló, létezést állító egzisztenciálisok esetében a lokatívuszi összetevő elhagyását, annak ellenére, hogy atelikus, határozottsági korlátozást mutató predikátumú szerkezetekről van szó. A kérdés megválaszolásához először meg kell vizsgálnunk a kétféle egzisztenciális szerkezet pragmatikai jellemzőit a korpuszmintában.

\section{Pragmatikai jellemzők}

\subsection{Leíró funkció}

Egy másik vizsgálat során, amelyben ugyanezen korpusz alapján az alany szintaktikai pozícióját befolyásoló tényezőket tanulmányoztam (Gécseg 2019), azt a megfigyelést tettem, hogy azok az egzisztenciális szerkezetek, amelyek alanya az igemódosító pozíciójában áll, tipikusan leíró funkciójú diskurzusrészekben fordulnak elő, függetlenül attól, hogy az alany puszta köznévi, vagy determináns vezeti be. Az ilyen megnyilatkozások révén a beszélő leírja (rendszerint felsorolja), hogy milyen objektum(ok) található(k) egy adott helyen, azaz egy adott helyhez 
hozzárendeli az ott található objektumo(ka)t. A leírások általában a fő esemény hátterét alkotják, és a leíró funkciójú megnyilatkozás a lokatívuszi összetevő révén tipikusan referenciális kapcsolatban van a szövegelőzménnyel. Ez magyarázza, hogy ezek a szerkezetek csak nagyon speciális esetekben használatosak diskurzuskezdő megnyilatkozásként.

(22) Nagy elörelépést jelent az új iskola. Virág van az ablakában.

(23) A dupla ágyat türkizkék ágytakaró borította. Mellette egy asztal volt, ami gyakorlatilag sminkasztalként funkcionált.

A lokalizáló egzisztenciálisok tehát jellemzően leírások, amelyeknek lényegi eleme a helyet jelölő összetevő. Ez a leíró funkció elsősorban az igemódosítói szerepű alanyt tartalmazó megnyilatkozásokat jellemzi, de ige utáni alanyú megnyilatkozásokhoz is társulhat.
Sikerült szereznem egy mindenhol hirdetett félelmetes nevű Police 500W lámpát. A csomagban volt egy lámpa, egy autós töltő, egy hálózati töltő, egy 18650-es elem, hozzá egy átalakító fehér henger és egy 3 férőhelyes AAA elemtartó.

\subsection{Topik bevezetése}

Az adatok azt mutatják, hogy a létezést állító egzisztenciálisok uralkodó pragmatikai funkciója egy új topik bevezetése, pontosabban egy olyan új referens bevezetése a diskurzusba, amely a következő megnyilatkozásban - vagy a diskurzus egészében - topikként jelenik meg (Gécseg 2019). ${ }^{13}$ A szövegnyelvészet Daneš (1974) nyomán ezt a fajta szövegszerveződést lineáris témafejlődésnek nevezi. Nem véletlen, hogy az ilyen megnyilatkozások a jobboldali kontextus (azaz a szövegfolytatás) felé orientáltak, ezért - a korpuszadatok tanúsága szerint is - gyakran fordulnak elő diskurzuskezdő helyzetben, pl. újságcikkek címében.

(25) Van egy nö. Szeret.

(26) Sajnos azt kell mondanom, volt egy ember, aki képtelen volt felnőni a pályán lévők játékához, illetve a mérkőzés színvonalához. Nem állítom, hogy a kárunkra tévedett a játékvezető - egyébként sem szeretek egy-egy játékhelyzetet kiemelni -, azt láttam, mindkét felet sújtotta téves ítéleteivel.

(27) Volt egy nő, úgy hívták, Emese.

(28) Volt egy kutya... Suzynak hívták.

Ilyen diskurzuskezdő helyzetben akár még a (25)-ben látható megnyilatkozás is elfogadható, de az esetek jelentős részében az egzisztenciális szerkezet által bevezetett új referenst egy vonatkozó tagmondatot tartalmazó névszói kifejezés jelöli. A (26)-os példában az egzisztenciális konstrukció alanya egy futballmérkőzés játékvezetőjét jelöli, ez a referens feleltethető meg a rákövetkező szövegrész diskurzustopikjának.

\footnotetext{
${ }^{13}$ Topik alatt itt „aboutness”-topikot értek (I. pl. Kuno 1972; Reinhart 1981; Gundel 1988; Lambrecht 1994), vagyis a topik szerepü összetevő azt a referenst jelöli, amelyröl a mondat által kifejezett propozíció szól.
} 
A létezést állító egzisztenciális megnyilatkozásokat a korpuszmintában több esetben olyan tagmondat követi, amely megnevezi az egzisztenciális szerkezet alanyának referensét ((27)-(28)). Mindez azt mutatja, hogy ezekben a szerkezetekben a határozatlan alany specifikus értelmezéssel bír, abban az értelemben, hogy az egzisztenciális állítás nem bármely, az alany névszói része által jelölt tulajdonsággal jellemezhető referensre igaz, hanem a határozatlan alany referenciája rögzített, a beszélő egy konkrét individuumot jelöl vele, akit ő azonosítani is tud. ${ }^{14}$ Ha nem így lenne, akkor minden Van egy $\mathrm{N}$-típusú kijelentés értelmezhetetlen volna - ahogy a (4a) példát furcsának is érezzük lokatívusz nélkül -, hiszen ha előfeltételezettnek tekintjük a köznév által jelölt individuumhalmaz létezését (amint az a legtöbb köznévre érvényes is), akkor semmilyen információértékkel nem bírna az a mondat, amely mindösszesen azt állítja, hogy létezik legalább egy eleme ennek az individuumhalmaznak. ${ }^{15}$

Mindezek alapján a következő választ fogalmazom meg arra a kérdésre, hogy miért nincs szükség térbeli lokalizációt jelölő kifejezésre az olyan egzisztenciálisokban, melyeknek fő pragmatikai funkciója egy új topik bevezetése:

Ezek a megnyilatkozások bizonyos hasonlóságot mutatnak a Van de Velde (2005) és Koch (2012) által vizsgált generikus olvasatú egzisztenciális szerkezetekkel. Itt sincs egy konkrét térbeli helyhez kötve az újonnan bevezetett individuum, hanem a megnyilatkozások azt állítják, hogy van/volt a világon - vagy egy adott szituációban - egy bizonyos individuum, aki vagy ami, mint a szövegfolytatásból kiderül, bizonyos tulajdonságokkal rendelkezik. Van de Velde (2005) alapján azt feltételezem, hogy az ilyen mondatok értelmezése nem valamiféle implicit térbeli lokalizáción alapul, hanem egy halmaz és annak eleme közti, más szóval partitív reláción. A (25)-ös mondat azt állítja, hogy a nők között van egy, aki szereti a beszélőt. A (26)-os mondat egy futballmérkőzés résztvevői közül egyről azt állítja, hogy nem nőtt fel a feladathoz. Az ilyen mondatok alanya nem gyenge olvasatú, hanem partitivuszi, azaz specifikus értelmezésű, más szóval individualizált. Ezt az individualizálást az ilyen szerkezetek alanyához gyakran kapcsolódó vonatkozó tagmondat teszi lehetővé. Az ilyen vonatkozó alárendelést tartalmazó főnévi kifejezések szintaktikai komplexitása gazdag jelentéstartalommal párosul, azaz az adott referenshez a köznév denotációján túl egy sor további tulajdonságot is hozzárendelünk. Ez a gazdag jelentéstartalom teszi lehetővé a határozatlan kifejezés individualizálását, és persze maga a szövegfolytatás is, melyben az újonnan bevezetett referens már topikként szerepel. Az individualizálás révén pedig, vagyis annak köszönhetően, hogy egyedivé tesszük és megkülönböztetjük a kategóriájába tartozó más individuumoktól, lehorgonyozható a referens, így nem igényel térbeli

\footnotetext{
${ }^{14}$ Hasonlóan a birtokos személyragot viselő alanyú egzisztenciális szerkezetekhez, ahol a határozatlan alany nem térben van lehorgonyozva, hanem a birtokviszony jóvoltából, amely egy szituációsan vagy kontextuálisan meghatározott birtokoshoz köti. Itt sincs szükség lokatívuszi összetevőre:

(i) Van egy kutyám.

${ }^{15}$ A Van egy gond-típusú, elvont fogalmat jelölő alanyú megnyilatkozások is ugyanezen okokból jólformáltak: a megnyilatkozás nem azt állítja, hogy létezik a világon legalább egy gond, hanem azt, hogy a beszélönek van egy gondja. Az egy gond NP referenciájának rögzítését, vagyis az NP referensének lehorgonyzását az a kapcsolat teszi lehetővé, ami ezt a referenst a beszélöhöz köti. Az egy gond határozatlan alany ilyen módon specifikus értelmezéssel bír.
} 
lokalizációt. Az individualizálás egyik legtisztább módja az, ha egy tulajdonnév révén megnevezzük az újonnan bevezetett referenst (I. (27) és (28)), de ugyanez elérhető úgy is, ha minél komplexebb, és ennek megfelelően minél gazdagabb szemantikai tartalmú NP-vel kódoljuk (26). Fontos szerepet játszik a referens ontológiája is. Nem véletlen, hogy az adatok nagy részében az ilyen lokatívusz nélküli megnyilatkozások alanya embert, társállatot (kutyát) vagy földrajzi helyet (tó, város) jelöl, hiszen ezek referense individualizálható azzal, hogy megnevezzük. Az ettöl eltérő típusú állatok, valamint a növények már sokszor nem is egyedként, hanem egy nagyobb rendszertani egység alosztályaként individualizáltak az egzisztenciális megnyilatkozásokban:

(29) Továbbá van egy bogár, amit lefényképezni nem tudtam, de nagyon érdekelne, hogy mi a neve.

(30) Van egy fa, ami áprilisban virágzik. Talán ez a legszebb dolog most a világon.

A (29)-es példa a bogarak egy bizonyos alfajáról szól, amelynek a beszélő nem tudta lefényképezni az eléje kerülő példányát. A bogaraknak az emberek életében betöltött szerepe, illetve az ezzel kapcsolatos ismereteink alapján nyilvánvaló, hogy a beszélő nem egy konkrét bogár nevéről érdeklődik, hanem a szóban forgó alfaj elnevezéséről. A (30)-as szövegrészlet egy olyan diskurzusból származik, amely a cseresznyevirágzásról szól. Az egzisztenciális megnyilatkozásban ennek megfelelően nem egy konkrét fa-példányról, hanem a japáncseresznye-fáról van szó általánosságban.

A fentiekben megfogalmazott hipotézis arra is magyarázatot ad, hogy miért érezzük rosszul formáltnak - kontextusból kiragadva - az itt (31)-ként megismételt (4a) mondatot:

\section{*Van egy csiga.}

A rendszertanilag alacsonyabb rendű állatokra általában nem mint individuumokra tekintünk, hanem mint a fajuk valamely egyedére. Az esetek többségében nem vagyunk képesek megkülönböztetni egymástól az egyes egyedeket, így ezek a referensek kevéssé individualizálhatók, nem is nagyon használjuk őket diskurzustopikként, legfeljebb mesékben. Az individualizálás egyetlen eszköze ilyenkor a térbeli lehorgonyzás, ezért az ilyen megnyilatkozások kötelező eleme lesz a lokatívuszi összetevő. A Google-keresés is kizárólag ilyen találatokat adott. ${ }^{16}$

A korpusz azon megnyilatkozásaiban, amelyek uralkodó pragmatikai funkciója egy új topik bevezetése a diskurzusba, az ige utáni alanyt mindig névelő vezeti be. Puszta köznév - gyenge referencialitása miatt - nem alkalmas erre a funkcióra. A korpusz mindazonáltal tartalmaz olyan megnyilatkozásokat, amelyekben az ige után álló puszta köznévi alanyt egy vonatkozói mellékmondat módosít:

(32) Volt ember, akinek ettől a fertőzéstől leesett az arca. Kérem, hagyják el a karantén területét.

\footnotetext{
${ }^{16}$ Persze még ebben az esetben is lehetséges olyan kontextust kreálni, amelyben még az ilyen megnyilatkozás is elfogadható:
}

(i) Van egy csiga. Be van horpadva a háza. Mindennap ott sütkérezik a teraszunkon. 
A (32)-es példa egy humoros jelenetben hangzik el, amelyben egy magát orvosnak kiadó férfi, két súlyos betegnek látszó férfi és azok hozzátartozói szerepelnek. A fenti szövegrészlet az „orvos” szájából hangzik el, a hozzátartozókhoz címezve. A benne szereplő egzisztenciális megnyilatkozás valójában nem egy konkrét individuumról szól, hanem egy (vagy több) olyan esemény létezését állítja, amelynek során az esemény résztvevőjének egy bizonyos fertőzés következtében leesett az arca. Ennek megfelelően a mondat a (32')-ben megadottak szerint parafrazálható:

Megesett/Megtörtént, hogy egy embernek ettől a fertőzéstől leesett az arca.

Egyes nyelvekben az ilyen típusú szerkezetek speciális aspektussal bírnak, melyet Comrie (1976) „tapasztalati perfektum”-nak (experiental perfect) nevez. A (25)-(30)-ban szereplő szerkezetekkel szemben a (32)-höz hasonló konstrukcióknak nem az a pragmatikai funkciója, hogy új referenst vezetnek be a diskurzusba, hanem azt fejezik ki, hogy egy bizonyos típusú szituáció már legalább egyszer előfordult a múltban.

\subsection{Elérhetöség}

A korpusz ige utáni puszta köznevet tartalmazó egzisztenciális szerkezeteinek többsége azonban nem a (32)-es példa sémájába illeszkedik. A (33)-(36)-os példa közös jellemzője, hogy ha van is bennük térbeli lokalizációt jelölő kifejezés, nem kötelező a jelenléte, és a létezés állításán túl a megnyilatkozás azt is kifejezi, hogy az adott típusú objektum jelenléte a szituációban hasznára van valakinek (rendszerint a beszélőnek vagy a hallgatónak).

(33) De addig is szolgáljátok ki magatokat, van üdítő a hűtőben, meg van ám kaja is, ha éhesek vagytok.

(34) Volt kenyér és cirkusz rogyásig.

(35) Van fa eladó.

(36) A baloldali falnál kétszemélyes ágy állt, ezenkívül volt asztal, szék...

(37) ??Van svábbogár (a lakásban).

Szemben az új topikot bevezető egzisztenciálisokkal, az ilyen szerkezetek alanya tipikusan élettelen objektumot jelöl, hiszen az alany referense nem mint individuum jelenik meg, hanem mint valamilyen funkció hordozója.

Megfigyelhető, hogy a fentebb megfogalmazott jelentésmozzanat (vagyis hogy az alany által jelölt objektum jelenléte hasznára van valakinek) a (33)-(36)-os példák mindegyikében a „rendelkezésre állás” vagy „elérhetőség” fogalmával ragadható meg leginkább. A fenti mondatok ebben a szórendi változatban és a fő összetevőkre eső egyenletes hangsúlykiosztással nem lennének jól formáltak még hangalakkal bíró lokatívuszi bővítménnyel sem, ha nem implikálnák azt, hogy az alany referense valamilyen hasznot hajt, valamilyen funkciót tölt be a szituáció egy vagy több résztvevője számára. Ezt erősíti a szövegkörnyezet is: a kontextus sokszor egy problémás helyzetet jelenít meg, amelyre az adott funkció megtestesítője megoldást jelent (33). A (37)-es mondat furcsa voltát pedig éppen az magyarázza, hogy 
nagyon nehéz olyan szövegkörnyezetet találni hozzá, amelyben valamilyen pozitív, hasznos szereppel ruházhatnánk fel a svábbogarakat. Az elérhetőség mozzanata sok esetben explicitté is tehető az egzisztenciális szerkezetek coda pozíciójában megjelenő melléknévi igenév (eladó, kiadó, átadó, l. (35)) jóvoltából.

Hasonló megállapítást tesz Paducheva (2008) az orosz hangalakkal bíró létigét és határozatlan alanyt tartalmazó mondatokra vonatkozóan, összevetve őket explicit létige nélküli változataikkal.

(Paducheva 2008: 152)

а. В этом дворе сторожевая собака. -ban ez udvar őrző kutya 'Ebben az udvarban házőrző kutya van.'

b. В этом дворе есть сторожевая собака. -ban ez udvar van őrző kutya 'Ebben az udvarban van házőrző kutya.'

A (38a) mondat lokalizáló egzisztenciális állításnak felel meg, (38b) pedig létezést állító egzisztenciálisnak. Az utóbbiban megjelenik az elérhető jelentéskomponens, mégpedig Paducheva (2008) elemzése szerint annak köszönhetően, hogy a házőrző kutya kifejezés szemantikai tartalmában benne van a funkció komponens, vagyis egy meghatározott használatot feltételez.

Mindez azonban nem magyarázza meg azt, hogy mi teszi lehetővé az ilyen mondatokban a hangalakkal bíró lokatívuszi összetevő elhagyását.

Az elérhető predikátum Kratzer (1995) sokat elemzett, itt (39) alatt idézett példája óta gyakran foglalkoztatja az egzisztenciális olvasatot kiváltó vagy megengedő predikátumokat kutatókat.

(Kratzer 1995: 125)

Firemen are available.

tüzoltók vannak elérhető

'Vannak elérhető tűzoltók.'

Amint arra a Kratzer (1995) elemzési javaslatát bírálók rámutattak, az, hogy a mondatnak helyzetkép-szintű predikátumot kell tartalmaznia, csupán egy szükséges, de nem elégséges feltétele annak, hogy az ilyen mondatoknak egzisztenciális olvasata (is) lehessen. Higginbotham-Ramchand (1997), valamint Jäger (1999) szerint az is kell az egzisztenciális olvasathoz, hogy a mondat jelentésébe bele legyen kódolva, hogy a szóban forgó esemény a beszélő (vagy narrátor) közelében megy végbe. Az available 'elérhető/rendelkezésre áll' predikátum esetében ez a feltétel teljesül is, ugyanakkor kétséges, hogy minden esetben fizikai közelségröl lenne szó. ${ }^{17}$

Az általam vizsgált korpusz azon megnyilatkozásaiban, ahol tetten érhető a predikátum elérhető jelentéskomponense, valóban megjelenik ennek a „közelség”nek a mozzanata, de a megnyilatkozások kontextusa nem feltétlenül térbeli közelségre utal, és nem is mindig a beszélöhöz van közel az objektum, amelynek a

\footnotetext{
${ }^{17}$ Higginbotham-Ramchand (1997) és Jäger (1999) magyarázatának bírálatáról és egy további megoldási javaslatról lásd Cohen-Erteschik-Shir (2002)-t.
} 
rendelkezésre állásáról szó van. Feltételezésem szerint a rendelkezésre állást implikáló megnyilatkozásokban a határozatlan alany referensének lehorgonyzását az teszi lehetővé, hogy az elérhető/rendelkezésre áll predikátumnak van egy fogadó (beneficiary) thematikus szerepű argumentuma. Ez az argumentum a vizsgált megnyilatkozásokban vagy a beszélőt (illetve a narrátort), vagy a hallgatót, esetleg mindkettőt jelöli: ők azok, akik a rendelkezésre áló dolog potenciális használói. A lokalizációt tehát nem térbeli lokalizációként kell érteni itt, hanem személyhez való hozzákötöttségként, hasonlóan a birtokviszonyt kifejező egzisztenciális szerkezetekhez, ahol a birtokos ugyanolyan lehorgonyzó szerepet tölt be, mint a térbeli lokalizáció:

(40) Van üdítőm/borom.

(41) ??Van svábbogaram.

Az új topikot bevezető egzisztenciális szerkezetekhez hasonlóan itt is azzal magyarázhatjuk a lokatívuszi összetevő opcionalitását, hogy a határozatlan alany referensének lehorgonyzása alternatív módon történik: míg az új topikot bevezető szerkezeteknél a szituációban való lehorgonyzást az alany referensének individualizálása teszi lehetővé, az ige utáni puszta köznévi alanyú megnyilatkozásokban azáltal lesz lehorgonyozva ez a referens, hogy a predikátum elérhető jelentéskomponense hozzákapcsolja az őt potenciálisan használó személyhez, aki nem más, mint a diskurzus egyik (vagy mindkét) résztvevője.

\section{A lokatívuszi összetevő szintaktikai pozíciója}

A teljes korpusz megnyilatkozásainak mintegy háromnegyed része tartalmaz térbeli lokalizációt jelölő összetevőt; ezeknek kb. 60 százalékában a lokatívusz a mondat elején, topik pozícióban áll, ${ }^{18}$ a maradék 40 százalékban pedig az egzisztenciális szerkezetet tartalmazó tagmondat végén áll. Mindez némileg meglepő lehet, ha figyelembe vesszük, hogy a magyar egzisztenciális mondatokkal foglalkozó tanulmányok példamondataiban a lokatívusz rendszerint a mondat végén helyezkedik el.

(42) Az épületben egy nő volt, aki elhunyt a tǔzben.

(43) Virtualion közelében volt egy tó. Három oldalról magas, meredek sziklafal vette körbe,

(44) Egy bogár van a fülemben.

(45) Van egy kutya a kertjében, asszonyom - válaszoltuk.

A lokatívusz mondatbeli helyzete összefüggést mutat az alany pozíciójával: a térbeli lokalizációval bevezetett megnyilatkozások jó kétharmadában ige utáni alany szerepel (43), míg tagmondat végi lokatívusznál a megnyilatkozások mintegy háromnegyed részében az ige előtt áll az alany (44). Ez a korreláció a mondat eleji lokatívusz esetén szinte teljes mértékben egybeesik a megnyilatkozások

\footnotetext{
${ }^{18}$ Néhány megnyilatkozásban az ige előtti lokatívusz az igemódosító pozíciójában van; kivétel nélkül minden esetben az ott mutató névmásról van szó.
} 
diskurzusfunkció szerinti megoszlásával: a Loc-V-S típusú szerkezetek túlnyomó része új topikot vezet be (kisebb részük pedig leíró funkciójú). A mondat végi lokatívusznál már nem ilyen egyértelmű a helyzet, mivel itt nagyjából azonos eloszlást mutatnak a leíró funkciójú és az új topikot bevezető megnyilatkozások.

Megállapíthatjuk tehát, hogy az új topikot bevezető megnyilatkozások lokatívuszi összetevője rendszerint topik pozícióban van. Mindez azzal függhet össze, hogy az ilyen megnyilatkozások között sok fordul elő szövegkezdő helyzetben, ahol elsődleges funkciójuk a diskurzustopik bevezetése. Ezt a bevezetést szolgálja, mintegy előkészíti az alany referensét térben lehorgonyzó, kerettopikként ${ }^{19}$ funkcionáló lokatívuszi kifejezés, ahogy azt a (43)-as példában is láthatjuk.

A leíró funkciójú megnyilatkozásoknál már egyéb kontextuális tényezők is közrejátszhatnak a lokatívusz pozíciójának megválasztásában. Hasonlítsuk össze az alábbi (46)-os és (47)-es példákat:

(46) Egy lámpa volt az asztalon, az asztal pedig a kandalló mellett állt.

(47) A Three Stars apartmanház két légterü, a fürdőszoba elég nagy. A nappalit egy ajtó választja el a hálótól, így aki korábban kel, nem zavarja a másikat az alvásban. A nappaliban van egy asztal 2 székkel, kihúzható kanapé, konyha. A terasz nagy, mert mind a nappaliból mind pedig a hálóból ki lehet menni,

A (46)-os példában egy olyan leírást találunk, ahol az első megnyilatkozás végén, a kommenten belül elhelyezkedő lokatívuszi összetevője a következő megnyilatkozásban topik pozícióba helyezett alanyként jelenik meg. Jellegzetes diskurzusstratégia ez a leíró jellegű szövegekben: a lineáris témafejlődés (Daneš 1974) mintegy verbális leképezését adja annak a folyamatnak, melynek során a szemlélő tekintete végigsiklik az egymás közelében lévő tárgyakon. Az 5.2. részben már találkoztunk a lineáris témafejlődés stratégiájával az új topikot bevezető egzisztenciális szerkezetek kapcsán. Ott az egzisztenciális szerkezet alanya az, amely a következő megnyilatkozás topikjává válik. A (46)-os példában viszont, amelynek uralkodó diskurzus-funkciója a leírás, az első tagmondat egzisztenciális szerkezetében szereplő lokatívuszból lesz a következő tagmondat topik szerepü alanya, amely magát a lokalizált objektumot jelöli. Mindez a leíró szövegrészletek azon jellegzetes vonását tükrözi, hogy az adott helyen előforduló objektumok egy része egymáshoz képest van lokalizálva.

A (47)-es példa egy másik fajta diskurzusstratégiát illusztrál. Maga a szöveg egy apartmanban található helyiségek, illetve az azokban található bútorzat leírása. Az apartman egyes helyiségei az apartman mint diskurzustopik egy-egy altopikját alkotják, és ennek megfelelően az egyes megnyilatkozások topik pozíciójában állnak. Daneš (1974) nyomán ezt a szövegszervező stratégiát a szövegnyelvészet hipertémából levezetett témafejlődésnek nevezi.

${ }^{19}$ A kerettopik (frame-setting topic vagy stage topic, I. pl. Chafe (1976), Erteschik-Shir (1997), Nikolaeva (2001) és Lahousse (2007)) az aboutness-topiktól rendszerint elkülönített topiktípus. Az ilyen szerepü összetevő azt a (tér-, idő- vagy individuális) keretet jelöli, amelyen belül a mondat által kifejezett propozíció érvényes. 
A korpuszmintában behatárolható egy olyan megnyilatkozáscsoport is, amelyben mindig az ige utáni mezőben van a lokatívuszi összetevő. Ezek a megnyilatkozások se nem leíró, se nem topikbevezető funkcióval nem jellemezhetők, és az „elérhetőség" jelentés-összetevő sem jelenik meg bennük. Az alany rendszerint az ige előtt van, de találunk ige utáni alanyú példákat is. Pragmatikai szempontból az a közös az ilyen szerkezetekben, hogy valamiféle nem várt referens megjelenéséről tudósítanak, amely sok esetben negatív hatással van a beszélőre. Tipikus példa rájuk a (44)-(45)-ös megnyilatkozás. Az új topikot bevezető egzisztenciálisokhoz hasonlóan ezekre is jellemző, hogy nem igényelnek szövegelőzményt, ugyanakkor szövegfolytatásra sincs feltétlenül szükségük: mintegy „derült égből” (out of the blue) hangzanak el. A többi thetikus állításhoz hasonlóan egy információs blokkot alkotnak, és ebben az értelemben a lokatívuszi összetevő által denotált hely is az új információ része. Feltételezésem szerint ha elfogadjuk azt az állítást, hogy a thetikus megnyilatkozásoknak is van topikjuk, akkor az nem a konkrét helymegjelöléssel azonosítható a (44)-(45)-öshöz hasonló szerkezetek esetében, hanem azzal a szituációval, illetve annak tér-idő koordinátáival, amelynek keretében maga az állítás értelmezhető. Ha viszont a lokatívuszi kifejezés a topik pozíciójában van (mint (42)(43)-ban), akkor ez a konkrét helymegjelölés maga a megnyilatkozás topikja.

\section{Konklúzió}

Az egzisztenciális szerkezetek látszólagos egyszerüségük ellenére (a magyarban minimálisan egy létigéből és egy határozatlan alanyból, valamint az esetek egy részében egy lokatívuszi összetevőből állnak) sem szemantikai, sem pragmatikai síkon nem alkotnak homogén csoportot. Ha el is elfogadjuk, hogy egy referens létezésének álítása mindig feltételezi ennek a referensnek a lokalizálását, ez a viszony még a konkrét, fizikai objektumok esetén sem feltétlenül térbeli lokalizálásként ragadható meg.

Ebben a tanulmányban elsősorban arra a kérdésre kerestem a választ, hogy miként lehetséges, hogy egyes egzisztenciális megnyilatkozásokban kötelezően jelen van egy térbeli lokalizációt jelölő összetevő, míg más egzisztenciális megnyilatkozásokban nincs, vagy csak opcionálisan jelenik meg lokatívusz.

A korpuszadatok azt mutatták, hogy a magyar egzisztenciális megnyilatkozásokban a lokatívusz kötelezőségét nagyban befolyásolja a megnyilatkozás pragmatikai funkciója, ami az alany igéhez viszonyított helyzetére is hatással van. A leíró funkciójú egzisztenciálisok alanya tipikusan az igemódosító helyét foglalja el, a térbeli lokalizáció pedig mindig explicit módon megjelenik. Azokban a megnyilatkozásokban, amelyeknek a fő funkciója egy új topik bevezetése a diskurzusba, az alany rendszerint az ige után áll, hangalakkal bíró lokatívusz pedig nem feltétlenül jelenik meg a szerkezetben. A vizsgált egzisztenciálisok harmadik típusa azt fejezi ki, hogy az alany által jelölt halmaz valamely eleme elérhető a beszélő és/vagy a hallgató számára. Ezekben a szerkezetekben az alany puszta köznévi, az ige után áll, és az esetek egy részében nincs jelen hangalakkal bíró lokatívusz.

Az adatok alapján a lokatívusz szintaktikai pozícióját illetően az állapítható meg, hogy a mondat eleji (topik pozícióban álló) lokatívusz legtöbbször ige utáni alannyal áll, a megnyilatkozás fő pragmatikai funkciója egy új topik bevezetése, a lokatívusz pedig kerettopikként funkcionál. A leíró funkciójú megnyilatkozásokban nem ilyen 
kötött a lokatívusz helye, hanem az adott diskurzusstratégia is befolyásolja. Azokban a megnyilatkozásokban, amelyek azt implikálják, hogy az alany referensének adott helyen való felbukkanása váratlan, a lokatívusz rendszerint az ige után, azaz a megnyilatkozás komment részében található, és az általa jelölt hely maga is az új információ része.

A korpuszvizsgálat során az is kiderült, hogy az alany referencialitása meghatározó szerepet játszik ebben a tekintetben, de a referencialitás mértéke nem csupán a névelős köznévi alanyt állítja szembe a puszta köznévi alannyal, hanem az egyes névelős határozatlan kifejezések referencialitásának, pontosabban specifikusságának mértéke egymástól is eltérhet. A kontextus kiemelkedő szerepet játszik ebben: így például az alanyt módosító vonatkozó mellékmondat alkalmas arra, hogy gazdag jelentéstartalma révén egy sor tulajdonsággal ruházza fel az alany referensét, és az ily módon individualizált referensnek nem feltétlenül van szüksége térbeli lehorgonyzásra. Az egzisztenciális szerkezetek kontextuális jellemzőinek elemzése arra is rávilágított, hogy egy referens, melynek létezését állítjuk, nem csak térben lokalizálható, hanem egy halmazon belül, vagy egy kitüntetett státuszú individuumhoz képest is, mint amilyenek a diskurzus résztvevői. A diskurzusban való lehorgonyzás tehát bizonyos feltételek mellett halmazhoz vagy személyhez kötés révén is megvalósulhat ezekben a szerkezetekben.

Maga a korpusz korlátozott méreténél fogva nem alkalmas arra, hogy szigorú szabályszerüségeket tudjunk megfogalmazni, és minden olyan paramétert megvizsgálhassunk, amely befolyásolhatja a lokativusz megjelenését. A keresési módszer korlátai miatt nem vizsgáltam például a determinánssal bevezetett jelzős szerkezeteket. Az egységesség kedvéért kimaradtak a vizsgálatból a többes számú puszta köznevek és az eseményt vagy valamilyen szituációt jelölő főnevek is. Maleczki (2008) ez utóbbiakról megállapítja, hogy bár ezek tipikusan az igemódosító pozíciójában állnak, az objektumot jelölő puszta köznévi alannyal szemben soha nem jelenik meg velük kötelezően lokatívuszi kifejezés:

$$
\text { Lakógyűlés van (a lépcsőházban). }
$$

Ennek a mintegy 200 megnyilatkozásból álló korpuszmintának a vizsgálata mindazonáltal előtanulmányul szolgálhat más, átfogóbb és több paramétert tekintetbe vevő vizsgálatoknak, amelyek megerősíthetik vagy tovább árnyalhatják az itt megfogalmazott általánosításokat és hipotéziseket.

\section{Köszönetnyilvánítás}

A tanulmány elkészítését a 120073. sz. NKFIH pályázat („Open access book series on the syntax of Hungarian") támogatta. Köszönetet szeretnék mondani továbbá a tanulmány két névtelen lektorának tanácsaikért és segítő kritikai megjegyzéseikért. A dolgozatban maradt hibákért engem terhel a felelősség. 


\section{Hivatkozások}

Chafe, Wallace L. 1976. Givenness, contrastiveness, definiteness, subjects, topics, and point of view. In Charles N. Li (szerk.) Subject and Topic. New York: Academic Press. 25-55.

Cohen, Ariel - Nomi Erteschik-Shir 2002. Topic, focus, and the interpretation of bare plurals. Natural Language Semantics 10/2:125-165. doi:10.1023/A:1016576614139.

Comorovski, lleana 1995. On quantifier strength and partitive noun phrases. In Emmon Bach - Eloise Jelinek - Angelika Kratzer - Barbara H. Partee (szerk.) Quantification in Natural Languages. Dordrecht: Kluwer. 145-177.

Creissels, Denis 2014. Existential predication in typological perspective. Kézirat. Université de Lyon.

Daneš, František 1974. Functional sentence perspective and the organization of the text. In František Daneš (szerk.) Papers in Functional Sentence Perspective. Prague: Academia. 106-128.

Enç, Mürvet 1991. The semantics of specificity. Linguistic Inquiry 22/1:1-25.

Erteschik-Shir, Nomi 1997. The Dynamics of Focus Structure. Cambridge: Cambridge University Press.

Gécseg, Zsuzsanna 2019. The syntactic position of the subject in Hungarian existential constructions. Argumentum 15:545-560.

Gundel, Jeanette K. 1988. Universals of topic-comment structure. In Michael Hammond - Edith A. Moravcsik - Jessica Wirth (szerk.) Studies in Syntactic Typology. (Typological Studies in Language 17) Amsterdam: John Benjamins Publishing Company. 209-239. doi:10.1075/tsl.17.16gun.

Hegedűs, Veronika 2013. Non-verbal Predicates and Predicate Movement in Hungarian. Utrecht: LOT.

Higginbotham, James - Gillian Ramchand 1997. The stage-level/individual-level distinction and the mapping hypothesis. Oxford University Working Papers in Linguistics, Philology and Phonetics 2:53-83.

Hoop, Helen de 1995. On the characterization of the weak-strong distinction. In Emmon Bach - Eloise Jelinek - Angelika Kratzer - Barbara H. Partee (szerk.) Quantification in Natural Languages. Dordrecht: Kluwer. 421-450.

Höhle, Tilman N. 1992. Über Verum-Fokus im Deutschchen. In Joachim Jacobs (szerk.) Informationsstruktur und Grammatik. (Linguistische Berichte Sonderhefte 4) Berlin: Springer. 112-142.

Jäger, Gerhard 1999. Stage levels, states, and the semantics of the copula. ZAS Papers in Linguistics 14:63-94.

Kálmán, László 1985a. Word order in neutral sentences. In István Kenesei (szerk.) Approaches to Hungarian 1. Szeged: JATE. 13-23.

Kálmán, László 1985b. Word order in non-neutral sentences. In István Kenesei (szerk.) Approaches to Hungarian 1. Szeged: JATE. 25-37.

Kálmán László (szerk.) 2001. Magyar leíró nyelvtan. Mondattan 1. (Segédkönyvek a nyelvészet tanulmányozásához 6) Budapest: Tinta Könyvkiadó.

Kiefer Ferenc 2006. Aspektus és akcióminöség, különös tekintettel a magyar nyelvre. Budapest: Akadémiai Kiadó. 
Koch, Peter 2012. Location, existence, and possession: A constructional-typological exploration. Linguistics 50/3:533-603. doi:10.1515/ling-2012-0018.

Kratzer, Angelika 1995. Stage-level and individual-level predicates. In Gregory N. Carlson - Francis Jeffry Pelletier (szerk.) The Generic Book. Chicago: University of Chicago Press. 125-175.

Kuno, Susumu 1972. Functional sentence perspective: A case study from Japanese and English. Linguistic Inquiry 3/3:269-320.

Laczkó, Tibor 2012. On the (un)bearable lightness of being an LFG style copula in Hungarian. In Miriam Butt - Tracy Holloway King (szerk.) Proceedings of the LFG12 Conference. Stanford: CSLI Publications. 341-361.

Lahousse, Karen 2007. Implicit stage topics. A case study in French. Discours/1. doi:10.4000/discours.117.

Lambrecht, Knud 1994. Information Structure and Sentence Form: Topic, Focus, and the Mental Representations of Discourse Referents. Cambridge: Cambridge University Press.

Link, Godehard 1983. The logical analysis of plurals and mass terms: A latticetheoretical approach. In Rainer Bäuerle - Christoph Schwarze - Arnim von Stechow (szerk.) Meaning, Use, and Interpretation of Language. Berlin, Boston: De Gruyter. 303-329. doi:10.1515/9783110852820.302.

Lyons, John 1967. A note on possessive, existential and locative sentences. Foundations of Language 3/4:390-396.

Maleczki Márta 1998. A határozatlan alanyok különféle értelmezései a magyar semleges mondatokban. In Büky László - Maleczki Márta (szerk.) A mai magyar nyelv leírásának újabb módszerei 3. Szeged: Szegedi Tudományegyetem. 261-280.

Maleczki, Márta 1999. Weak subjects in fixed space. Acta Linguistica Hungarica 46/1-2:95-117.

Maleczki Márta 2001. Az információs szerkezet, a szintaktikai szerkezet és az aspektus összefüggései a magyarban. A progresszív és az egzisztenciális aspektus. In Bakró-Nagy Marianne - Bánréti Zoltán - É. Kiss Katalin (szerk.) Újabb tanulmányok a strukturális magyar nyelvtan és a nyelvtörténet köréból (Kiefer Ferenc tiszteletére barátai és tanítványai). Budapest: Osiris Kiadó. 165-181.

Maleczki, Márta 2003. Information structure, argument structure, and typological variation. In Katarzyna M. Jaszczolt - Ken Turner (szerk.) Meaning Through Language Contrast. (Pragmatics \& Beyond New Series 99) Amsterdam: John Benjamins Publishing Company. 223-244. doi:10.1075/pbns.99.19mal.

Maleczki Márta 2008. Határozatlan argumentumok. In Kiefer Ferenc (szerk.) Strukturális magyar nyelvtan 4. A szótár szerkezete. Budapest: Akadémiai Kiadó. 129-184.

McNally, Louise 2016. Existential sentences crosslinguistically: Variations in form and meaning. Annual Review of Linguistics 2/1:211-231. doi:10.1146/annurev-linguistics-011415-040837.

Milsark, Gary L. 1974. Existential sentences in English. PhD disszertáció. MIT, Cambridge. 
Németh Boglárka 2012. Az aspektus a magyar nyelvben: különös tekintettel a statikusságra. (Segédkönyvek a nyelvészet tanulmányozásához 144) Budapest: Tinta Könyvkiadó.

Nikolaeva, Irina 2001. Secondary topic as a relation in information structure. Linguistics 39/1:1-49. doi:10.1515/ling.2001.006.

Paducheva, Elena V. 2008. Locative and existential meaning of Russian быть. Russian Linguistics 32/3:147-158. doi:10.1007/s11185-008-9027-2.

Partee, Barbara H. - Vladimir Borschev 2007. Existential sentences, BE, and the genitive of negation in Russian. In lleana Comorovski - Klaus von Heusinger (szerk.) Existence: Semantics and Syntax. (Studies in Linguistics and Philosophy) Dordrecht: Springer. 147-190.

Puskas, Genoveva 2000. Word Order in Hungarian. The syntax of $\bar{A}$-positions. (Linguistic Aktuell / Linguistics Today 33) Amsterdam: John Benjamins Publishing Company.

Reinhart, Tanya 1981. Pragmatics and linguistics: An analysis of sentence topics. Philosophica 27:53-94.

Van de Velde, Danièle 2005. Les interprétations partitive et existentielle des indéfinis dans les phrases existentielles locatives. Travaux de linguistique 50/1:37-52. doi:10.3917/tl.050.0037.

Viszket Anita 2004. Argumentumstruktúra és lexikon. PhD disszertáció. Budapest: Eötvös Loránd Tudományegyetem.

\section{A szerzőről}

Gécseg Zsuzsanna az SZTE Francia Tanszékének docense. Tudományos érdeklődése középpontjában a szintaxis, a szemantika és a pragmatika interakciója áll, különös tekintettel a mondat információs szerkezetére.

Elérhetősége: gecsegz@lit.u-szeged.hu 